\title{
Clarification of Reprocessed Syrup and Use in the Formulation of Lollipop-Type Hard Candies
}

\author{
Carolina Elisa Demaman Oro ${ }^{1 \mathbb{D}}$, Bruna Maria Saorin Puton ${ }^{1 \mathbb{D}}$, Verônica Baldon Fusinato ${ }^{1 \mathbb{D}}$, Cíntia \\ Marciniak $^{2}$ (D) , Andressa Franco Denti ${ }^{3}$ (D), Julia Lisboa Bernardi ${ }^{3}$ (D), Bethina Pascuetti Tres ${ }^{3}$ (D), Natalia \\ Paroul $^{3(i)}$, Eunice Valduga ${ }^{2(D)}$, Juliana Steffens ${ }^{2, * i D}$, Rogério Marcos Dallago ${ }^{3}$ (D) \\ 1 Graduate Program in Food Engineering, Universidade Regional Integrada do Alto Uruguai e Missões, Av. Sete de \\ Setembro, 1621, 99700-000 Erechim - RS, Brazil \\ 2 Department of Agrarian Sciences, Universidade Regional Integrada do Alto Uruguai e Missões, Av. Sete de Setembro, \\ 1621, 99700-000 Erechim - RS, Brazil \\ 3 Department of Exact Sciences, Universidade Regional Integrada do Alto Uruguai e Missões, Av. Sete de Setembro, 1621, \\ 99700-000 Erechim - RS, Brazil \\ * Correspondence: julisteffens@uricer.edu.br;
}

Scopus Author ID 22036040400

Received: 30.04.2020; Revised: 22.05.2020; Accepted: 25.05.2020; Published: 27.05.2020

\begin{abstract}
The objective was to evaluate the removal of dye using activated carbon, and apply the best condition in the removal of candy reprocessing syrup pigment, as well as to evaluate its influence in the visual aspect of a lollipop. Adsorption capacity tests were performed with the dye diluted with and without sucrose, and from the data, the linearization of the Langmuir and Freundlich isotherms were calculated. The lollipop was prepared with syrup treated with activated carbon and visually evaluated using a panel of untrained tasters. The Freundlich isotherm adjusted more appropriately to the experimental data of the adsorption of the dye diluted in distilled water, while for the dye diluted in sucrose solution, the most suitable model was Langmuir's. The experimental design condition showed the highest adsorptive capacity $\left(26.91 \mathrm{mg} \cdot \mathrm{g}^{-1}\right)$ for the dye diluted in the aqueous solution was at a temperature of $60^{\circ} \mathrm{C}$ and $\mathrm{pH} 5.5$, while for the sucrose-diluted dye solution, was $103.09 \mathrm{mg} . \mathrm{g}^{-1}$, under the same conditions. The visual evaluation of the lollipop indicated the possibility of adding up to $15 \%$ of reprocessing syrup. Thus, the use of activated carbon is an alternative to remove the coloring from candy syrup and enable its reuse within the industry.
\end{abstract}

Keywords: Candies residue; Adsorption isotherm; Activated carbon; Clarification; Lollipop.

(c) 2020 by the authors. This article is an open-access article distributed under the terms and conditions of the Creative Commons Attribution (CC BY) license (https://creativecommons.org/licenses/by/4.0/).

\section{Introduction}

The food industry, especially candies, is characterized by the generation of high volumes of effluents and residues at the different stages of the production process. These are usually difficult to treat due to the complexity of their compositions, such as fats, sugars, and additives, which include flavorings, preservatives, and dyes [1,2].

Thus, their reuse, in addition to relieving the treatment plants, is a viable alternative to avoid or reduce the waste of high added value ingredients and limit treatment or disposal costs [3].

Among the different residues, the non-conforming finished product, characterized by unfeasible commercialization, is highlighted. This product is usually re-melted and stored in the form of reprocessing syrup to be reused in the composition of new products. Regarding its reuse, pigmentation is presented as a limiting factor, directing its application to products with 
the same pigmentation or darker tones. In this context, the removal of pigmentation from this reprocessing syrup would expand its application to new products.

The removal of pigmentation, whether from effluents, residues, or finished products, can be carried out using oxidative processes, such as ozone or hydrogen peroxide, or even by adsorptive processes [4].

In oxidative processes, color removal occurs through oxidative degradation leading to chemical changes in the pigment structure, with the generation of by-products, which in many cases lead to an increase in the toxicity of this residue, something undesirable when reuse in food preparation is the objective. This characteristic is not observed in the adsorptive processes, which are based on the phase transfer of the pollutant/pigment, without generating by-products [5].

Among the adsorbents, activated carbon is one of the most used for the removal of natural and artificial dyes, because, in addition to its high efficiency, it does not modify the other characteristics of the treated food [6,7].

In addition to being used in the adsorption of textile dyes and water treatment $[4,8,9]$, several studies have applied activated carbon to remove color in food products, such as cheese whey [10,11], Japanese soy sauce [12], tea and coffee infusions [13], beet molasses [6], vinegar [14], sunflower oil [15], cotton and neem seeds oil [16], Pereskia aculeata [17], raw cane juice [18], fruit candy syrup [5] and candy syrup [19].

The removal of dyes through adsorption using activated carbon, such as the case of candy syrup, allows a percentage of the discolored syrup to be reintroduced into the production line, being mixed with the initial ingredients, such as water, sugar, and glucose among others, without causing unevenness in the color of the final product.

In this sense, the objective of the present work was to study color removal from a reprocessing syrup from a local candies industry, using commercial activated carbon as an adsorbent agent and through visual sensory analysis, evaluate the application of the treated syrup in the elaboration of lollipop-type hard candy.

In order to optimize the experimental treatment conditions, preliminary studies were conducted using the bright blue food coloring as a model molecule, diluted in distilled water, and in a sucrose solution $45^{\circ}$ Brix.

\section{Materials and Methods}

\subsection{Characterization of adsorbents.}

\subsubsection{Optical microscopy.}

Activated carbon, in powder and granular form, was deposited on slides, and photographs were taken at 40x magnification with the aid of a photographic camera (Moticam 580, model 0715 CVDA -580) coupled to an optical microscope (Zeiss, Standard 20 model).

\subsubsection{Determination of granulometry.}

The average particle diameter was determined by weighing $10 \mathrm{~g}$ of powdered and granulated activated carbon, which were sieved in 20,40,60, 100, and 325-mesh screens (Tyler screens). The retained substance in each mesh was weighed and compared with the initial mass. 
2.1.3. Determination of the iodine number of activated carbon.

The characterization of the surface area of activated carbon, in powder and granulated forms, was carried out using the iodine number method, according to the ABNT MB-3410 standard [20], but none underwent a grinding or screening process.

\subsubsection{Determination of the Zeta Potential.}

The flow potential was determined in an electrokinetic analyzer (SurPASS, Anton Paar $\mathrm{GmbH}$, Austria), using a measurement cell for solid samples (glass cylinder cell with $25 \mu \mathrm{m}$ filter disc). For each analysis, $500 \mathrm{mg}$ of solid samples (with particle size greater than $25 \mu \mathrm{m}$ ) were used. Before starting the measurement, the samples were carefully washed with the measurement electrolyte, a $10^{-3}$ mol. $\mathrm{L}^{-1} \mathrm{KCl}$ solution, and the $\mathrm{pH}$ of the aqueous solution was adjusted with 0.1 mol. $\mathrm{L}^{-1} \mathrm{HCl}$ and $\mathrm{NaOH} 0.1$ mol.L ${ }^{-1}$.

\subsection{Characterization of the bright blue dye and reprocessing syrup solutions.}

\subsubsection{Spectrophotometric analysis and calibration curve.}

The regions where each sample absorbs radiation was determined spectrophotometrically using a UV-Vis spectrophotometer (Agilent, model 8453), operating in scan mode.

The quantification of the bright blue food coloring (C.I. 42090) (Figure 1) was performed using a calibration curve with external standards $\left(0.5 ; 1 ; 2 ; 5 ; 10 ; 15\right.$ and 20 mg.. - $^{-}$ $\left.{ }^{1}\right)$. The spectrum of the reprocessing solution was carried out without diluting it.

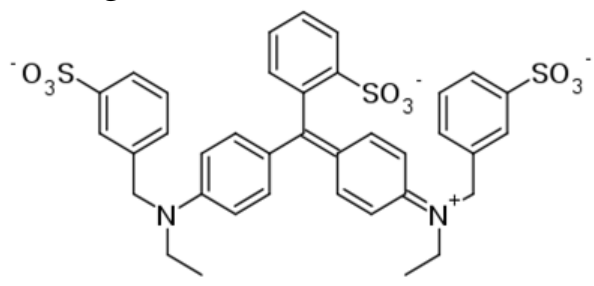

Figure 1. Structural formula of food coloring bright blue (C.I. 42090); adapted from [21].

2.2.2. Determination of $\mathrm{pH}$ and sugar content ( $\left.{ }^{\circ} \mathrm{Brix}\right)$.

The $\mathrm{pH}$ was analyzed using a digital $\mathrm{pH}$ meter (Digimed, DM-22), and the sugar content was determined using a refractometer (Biobrix).

\subsubsection{Objective color determination.}

The objective color was determined in a colorimeter CR-400 Minolta Chroma meter (Konica Minolta Sensing Americas, Inc) in the CIELAB color space, where L* is luminosity, $a^{*}$ is the intensity of red color and $b^{*}$ is the intensity of yellow color [22].

The parameter $\mathrm{C}^{*}$ (Chroma), which shows the color saturation of the object, was evaluated according to Equation (1), and the Hue-Angle $\left(\mathrm{H}^{\circ}\right)$, which indicates the color tone, was obtained according to Equation 2.

$$
\begin{aligned}
& C^{*}=\sqrt{\left(\boldsymbol{a}^{*}\right)^{2}+\left(\boldsymbol{b}^{*}\right)^{2}} \\
& \mathrm{H}^{\mathrm{o}}=\tan ^{-1}\left(\frac{\mathrm{b}^{*}}{\mathrm{a}^{*}}\right)
\end{aligned}
$$




\subsection{Adsorptive tests with bright blue dye.}

\subsubsection{Adsorption kinetics.}

The contact time required for the dye-adsorbent system to reach equilibrium was determined in a kinetic study with a solution of the bright blue dye diluted in distilled water and another with the same dye diluted in sucrose solution $45^{\circ}$ Brix (sucrose concentration used in industry), both solutions at a concentration of $250 \mathrm{mg} . \mathrm{L}^{-1}$.

Powdered or granulated activated carbon $(0.1 \mathrm{~g})$ and $30 \mathrm{ml}$ of the dye solutions were added in $100 \mathrm{ml}$ glass flasks. The flasks were later submitted to constant agitation (100 rpm) in an orbital shaker (Nova Ética, $430 \mathrm{RDB})$ at room temperature $\left(25^{\circ} \mathrm{C}\right)$ for 120 minutes.

The tests were destructive, and aliquots of $0.5 \mathrm{~mL}$ of the solution were removed, in triplicate, with the aid of a micropipette, added in $25 \mathrm{~mL}$ volumetric flasks for dilutions with distilled water and then centrifuged at 1,200 rpm (Hettich, 200424). The readings were performed by spectrophotometer (Pró-Analise $\left.{ }^{\circledR}, \mathrm{UV}-1600\right)$ at $628 \mathrm{~nm}(\lambda \max )$.

\subsubsection{Adsorptive capacity of powdered activated carbon.}

The adsorption capacity was determined by batch tests using solutions of the dyes, with and without sucrose, in concentrations of 50, 100, 300, 500, 800, and $1000 \mathrm{mg} . \mathrm{L}^{-1}$.

The experiments were carried out in $40 \mathrm{ml}$ plastic flasks containing $0.1 \mathrm{~g}$ of activated carbon and $30 \mathrm{ml}$ of the dye solutions with and without sucrose, under mechanical agitation in an orbital shaker at $100 \mathrm{rpm}$, for 1 hour. The adsorption was accompanied by UV-Vis spectrophotometry, monitoring the absorption of the dye at a wavelength of $628 \mathrm{~nm}$.

Adsorption in a solid-liquid system removes the solutes from the solution, accumulating them on the surface of the solid until reaching dynamic equilibrium. The amount of solute that can be absorbed as a function of temperature, solution concentration, and process, at a constant temperature, can be described by an adsorption isotherm according to Equation (3) [23]:

$$
q t=\frac{(C o-C t) * V}{m}
$$

Where:

$q t\left(\mathrm{mg} \cdot \mathrm{g}^{-1}\right)$ is the amount of adsorbent per unit mass of adsorbent at time $\mathrm{t}$;

$C_{o}$ and $C_{t}\left(\mathrm{mg} . \mathrm{L}^{-1}\right)$ are the initial concentration and concentration at time $\mathrm{t}$ of adsorbate, respectively;

$V$ is the volume of the solution $(\mathrm{L})$;

$m$ is the mass of the adsorbent $(\mathrm{g})$.

\subsubsection{Optimization of the adsorption process.}

In order to optimize the adsorption process of the bright blue dye on activated carbon and to evaluate the influence of independent variables (temperature and $\mathrm{pH}$ ), a $2^{2}$ experimental design with triplicate at the point was carried out. The mass of activated carbon and the volume of the bright blue food coloring solution was fixed at $0.1 \mathrm{~g}$ and $30 \mathrm{ml}$, respectively. Table 1 presents the planning matrix with the real and coded values of the evaluated variables.

Table 1. Variables and levels studied in the $2^{2}$ factorial design for the dye adsorption tests at $70^{\circ} \mathrm{C}, 100 \mathrm{rpm}$, and $1 \mathrm{~h}$.

\begin{tabular}{c|c|c|}
\hline Variables/Levels & Temperature $\left({ }^{\mathbf{0}} \mathbf{C}\right)$ & $\mathbf{p H}$ \\
\hline $\mathbf{- 1}$ & 20 & 5.5 \\
\hline $\mathbf{0}^{*}$ & 40 & 7.0 \\
\hline $\mathbf{1}$ & 60 & 8.5 \\
\hline
\end{tabular}

* central point triplicate. 
The levels of the investigated variables took into account the lower $\mathrm{pH}$ limit as 5.5, in order to minimize the sucrose inversion, observed in tests conducted with lower $\mathrm{pH}$, the maximum temperature limit was $60^{\circ} \mathrm{C}$, to minimize the reaction of sucrose caramelization.

The $\mathrm{pH}$ was adjusted with a solution of sodium hydroxide $\left(0.1 \mathrm{~mol} . \mathrm{L}^{-1}\right)$ (Dynamic) or phosphoric acid (85\%; FMAIA). As a response, the amount of dye removed was evaluated.

Subsequently, the adsorption isotherms were evaluated for their adjustment to the Langmuir and Freundlich models. In order to fit the Langmuir theoretical model (Equation 4), the curves obtained were linearized, obtaining the $\mathrm{K}$ (equilibrium constant) and $\mathrm{N}$ (solute mass for adsorbent saturation) coefficients.

$$
\frac{C e q}{q e q}=\frac{1}{K N}+\frac{C e q}{N}
$$

For the adjustment of the isotherms to the Freundlich empirical adsorption model, Equation (5) was used, with $\mathrm{k}$ (adsorption capacity) and n (affinity of the adsorbent-adsorbate system) coefficients.

$$
\ln q e q=\ln k+\frac{1}{n \ln C e q}
$$

Where:

$C_{e q}$ is the concentration of the solution at equilibrium $\left(\mathrm{mg} . \mathrm{L}^{-1}\right)$;

$q e q$ is the amount of adsorbed (mg. $\left.\mathrm{g}^{-1}\right)$.

\subsection{Adsorption tests with the reprocessing solution.}

For the tests with a real sample, a candy reprocessing syrup was used, provided by a candy industry, located in the northern region of Rio Grande do Sul. The sample was characterized in terms of $\mathrm{pH},{ }^{\circ}$ Brix, absorbance spectrum, and objective color $\left(\mathrm{L}^{*}, \mathrm{a} *, \mathrm{~b}^{*}, \mathrm{C}^{*}\right.$, and $\mathrm{H}^{\circ}$ ).

For the adsorption tests with powdered activated carbon, the reprocessing solution was diluted until reaching $45^{\circ}$ Brix, simulating the concentration used in the industry. The experimental conditions were determined from the results obtained in the tests carried out with powdered carbon for the bright blue food coloring diluted with $45^{\circ}$ Brix sucrose solution, these being at a temperature of $60{ }^{\circ} \mathrm{C}$ and $\mathrm{pH}$ of 5.5. The powdered activated carbon masses used were based on the adsorptive test with the bright blue food coloring; these were $0.334 ; 0.834$; 1,667 and 3,334 g.L. ${ }^{-1}$.

2.4.1. Elaboration of lollipop hard candy from reprocessed syrup treated with activated carbon.

Lollipop-type hard candy formulations were developed on a laboratory scale. Initially, $200 \mathrm{~g}$ of traditional syrup was added at $45^{\circ}$ Brix (glucose, water, and sugar) in a $4 \mathrm{~kg}$ stainless steel container. Different concentrations of reprocessing solution $(0,10,15,20$, and $30 \%$, w/w $)$ were then added, treated with a concentration of 3.334 g.L. $\mathrm{L}^{-1}$ of powdered activated carbon.

The cooking step was carried out at a temperature of $190{ }^{\circ} \mathrm{C}$, for approximately 15 minutes, with constant agitation for greater homogenization and water evaporation. At the end of cooking, red dye 40 was added, and the mass was shaped with the aid of lollipop molds (mock-ups). The candies produced were evaluated for objective color and visual color. 


\subsubsection{Visual sensory analysis.}

The sensory analysis of the visual color of the hard candy samples, made with different concentrations of syrup treated with activated carbon, was carried out through visual evaluation by a team of 30 untrained judges, of both sexes, belonging to the age group of 20 to 50 years, being employees, academics and professors of URI Erechim. The samples (5 g) were distributed in plastic containers coded with random three-digit numbers and balanced distribution.

For the evaluation, a control difference test was applied, employing a 9-point scale, with the scale varying from 1-Extremely less intense than the standard, 5-Same as the standard and 9-Extremely more intense than the standard [24].

\subsection{Statistical analysis.}

The average values of the objective color parameters obtained were analyzed statistically by Analysis of Variance (ANOVA), followed by the Tukey test ( $p<0.05$ ), using the SAS program.

The results of the visual sensory analysis were treated statistically by analysis of variance (ANOVA), and the means were compared by the Dunnett test, with $95 \%$ confidence, using the Statistica version 5.0 program (Statsoft Inc, USA).

\section{Results and Discussion}

\subsection{Characterization of adsorbents.}

\subsubsection{Optical analysis and granulometry.}

Figure 2 shows the images obtained by an optical microscope, with a 40x image magnification, of the activated carbon in powder (a) and granulated (b). It is observed that powdered activated carbon has smaller particles than the granulated activated carbon. Table 2 shows the particle size distribution of activated carbon in powder and granules.

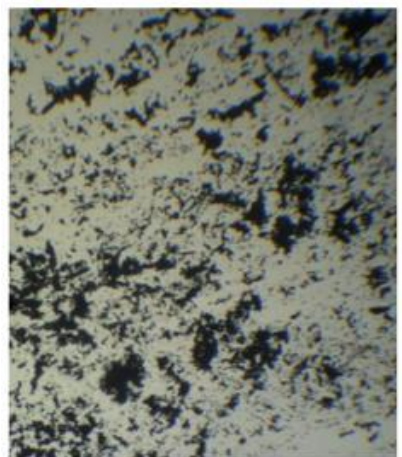

(a)

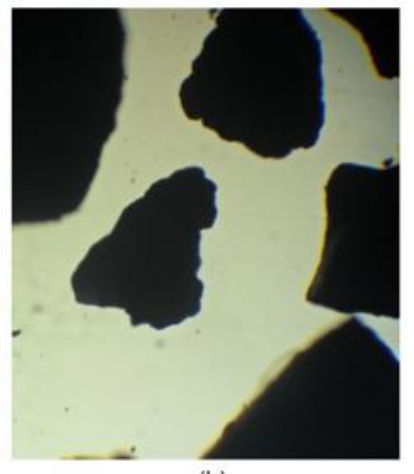

(b)

Figure 2. Microscopic images of powdered (a) and granulated (b) activated carbon, enlarged 40x.

Table 2. Particle size distribution of powder and granulated activated carbon.

\begin{tabular}{c|c|c|c} 
Mesh & $\begin{array}{c}\text { Diameter of the sieve } \\
\text { opening }(\boldsymbol{\mu m})\end{array}$ & $\begin{array}{c}\text { \% of retained } \\
\text { powdered carbon }\end{array}$ & $\begin{array}{c}\text { \% of retained } \\
\text { granulated carbon }\end{array}$ \\
\hline $\mathbf{2 0}$ & 850 & - & 75.7 \\
\hline $\mathbf{4 0}$ & 425 & - & 24.16 \\
\hline $\mathbf{6 0}$ & 250 & 1.05 & 0.13 \\
\hline $\mathbf{1 0 0}$ & 150 & 1.11 & 0.11 \\
\hline $\mathbf{3 2 5}$ & 45 & 20.6 & - \\
\hline$>\mathbf{3 2 5}$ & $<45$ & 77.14 & -
\end{tabular}


For powdered carbon, more than $77 \%$ of the particles passed through the 325-mesh screen, with $20.6 \%$ being retained in that mesh. For granulated activated carbon, most of the particles $(75.7 \%$ ) were retained in the 20 -mesh screen and about $24 \%$ in the 40 -mesh screen.

Powdered activated carbon has more than $97 \%$ of its particles with a diameter of fewer than $45 \mu \mathrm{m}$, that is, less than that observed for granulated activated carbon, which preferably presents $(>99 \%)$ particles with a diameter greater than $425 \mu \mathrm{m}$. These data complement what was seen in Figure 2, regarding the particle size.

It should be noted that the smaller the particle size, the larger the surface area tends to be, which directly influences the adsorptive capacity. In general, the larger the surface area, the greater its adsorption capacity [25].

\subsubsection{Iodine Number and Point of Zero Charge (PZC).}

The iodine number test expresses the amount of iodine that activated carbon is able to adsorb, being related to the adsorption of small molecular mass molecules [26].

In the tests carried out, the iodine number obtained for powdered carbon was $928.27 \pm$ $30.24 \mathrm{mgI} 2 . \mathrm{g}^{-1}$, whereas for granulated carbon, the value was $138.24 \pm 11.45 \mathrm{mgI} . \mathrm{g}^{-1}$, that is, a value of adsorption capacity approximately 7 times less than the value found for powdered activated carbon.

In their study of activated carbon production from Thapsia transtagana for dye removal, Machrouhi et al. [27] found an iodine number value of $794.58 \mathrm{mgI} 2 \mathrm{~g}^{-1}$, lower than that obtained in this work.

Evaluating the activated carbon used for the adsorption of the dye Remazol Yellow Gold RNL, Besinella Junior et al. [28] found a value of $864 \mathrm{mgI} . \mathrm{g}^{-1}$ for activated carbon. According to the authors, the iodine index expresses the number of micropores in the activated carbon with less than $40 \AA$ (Ångström).

The value of the Zeta Potential, that is, the $\mathrm{pH}$ equivalent to the Point of Zero Charge (PZC) obtained was 5.0, for both activated carbons. This pHPZC value indicates that for cationic dyes, due to the presence of $\mathrm{OH}$ functional group, its adsorption is favored at $\mathrm{pH}>\mathrm{pH}_{\mathrm{pzc}}$, whereas anionic dye adsorption is favored when $\mathrm{pH}<\mathrm{pH}_{\mathrm{pzc}}$, where the surface becomes positively charged [29].

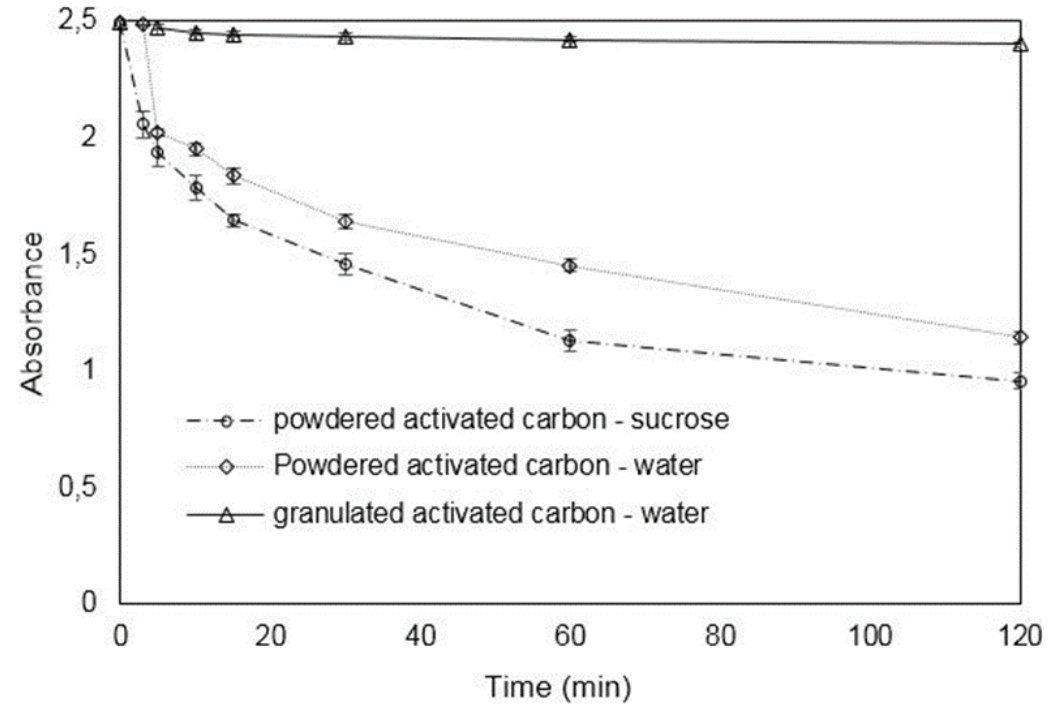

Figure 3. Effect of contact time on the adsorption of dye diluted in distilled water and sucrose solution $45^{\circ} \mathrm{Brix}$ for powdered activated carbon. 
3.2. Adsorptive tests with bright blue food coloring.

\subsubsection{Adsorption kinetics.}

The contact time in the adsorption process is an important parameter [30]. Figure 3 shows the adsorption kinetics of the dye diluted in distilled water and in a $45^{\circ}$ Brix sucrose solution for powdered carbon and the dye diluted in distilled water for granulated activated carbon.

According to Figure 3, granulated activated carbon reduced $3.7 \%$ of pigmentation in 120 minutes, being ineffective when compared to the powder form, which showed removals of $61 \%$ and $61.6 \%$ for aqueous and sucrose solution, respectively, probably due to its high surface area in relation to granulated carbon.

According to Aljeboree, Alshirif, and Alkaim [31], the increase in the adsorption capacity with the decrease of the particle size, may suggest that the dye is preferentially adsorbed on the external surface, not reaching the interior of the particle, due to the steric impediment of large dye molecules.

For both tests with powdered carbon, regardless of the solution (aqueous or sucrose), the same trend is observed, with a progressive increase in color removal as a function of contact time, with a more intense variation in the first 60 minutes (54 and 54.7\%, for aqueous and sucrose solutions, respectively). The small variation of removal observed between 60 and 120 minutes (about 7\%), suggests 60 minutes as contact time to be used for the other tests.

Among the tests with powdered activated carbon, the one carried out using a sucrose solution at $45{ }^{\circ}$ Brix showed better performance $(0.7 \%)$, when compared to the aqueous solution, suggesting that the sucrose molecules have little influence on the adsorption capacity of the carbon for this food coloring.

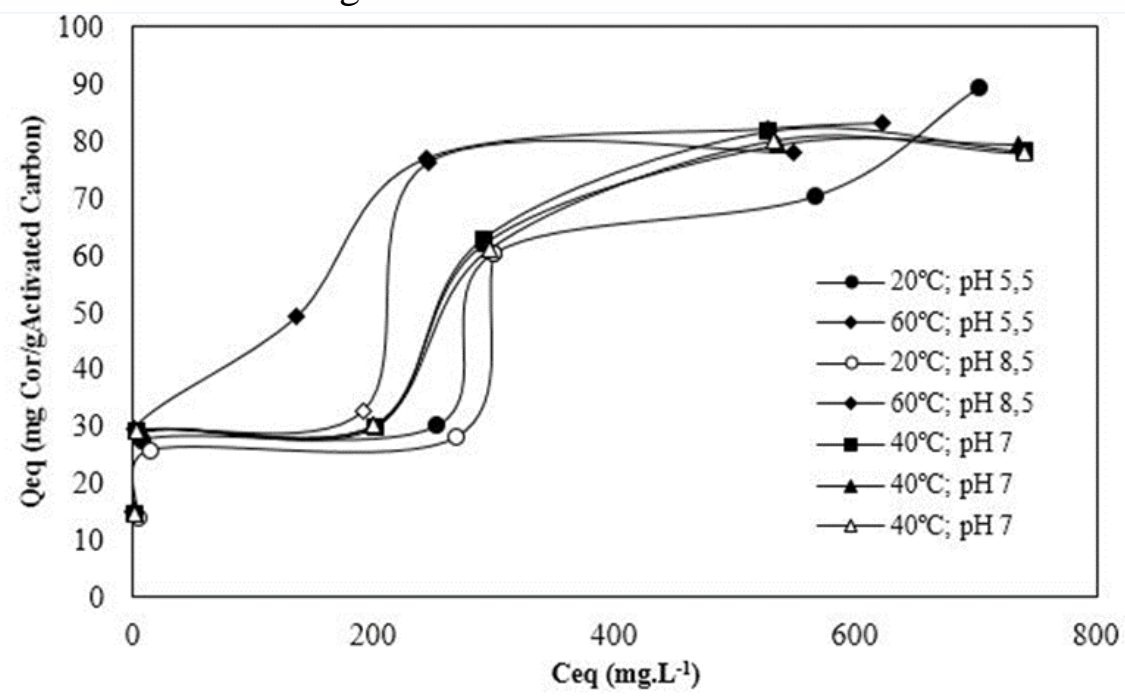

Figure 4. Sorption isotherms for the dye diluted in distilled water at different temperatures and $\mathrm{pH}$.

3.2.2. Adsorptive capacity for powdered activated carbon.

3.2.2.1. Effect of temperature and $\mathrm{pH}$ on the adsorptive capacity of aqueous solutions of bright blue food coloring.

The adsorption efficiency is influenced by several factors, such as adsorbent-adsorbent interaction, adsorbent surface area, adsorbent to adsorbent ratio, adsorbent particle size, temperature, $\mathrm{pH}$, and contact time [32,29]. 
Figure 4 shows the effect of $\mathrm{pH}$ and temperature $\left({ }^{\circ} \mathrm{C}\right)$, obtained by a $2^{2}$ factorial design, in the adsorption of the dye diluted in distilled water, using powdered activated carbon.

The profile observed for the isotherm shown in Figure 4 suggests that it is better suited to the Freundlich empirical model, which assumes that the heat distribution on the adsorbent surface is not uniform, that is, the adsorption is heterogeneous and occurs in multilayer [33].

Table 3 presents the planning matrix with the real and coded values of the independent variables and the values obtained from the Langmuir and Freundlich isotherms for the dye diluted in distilled water.

Table 3. Matrix of the $2^{2}$ experimental design (coded and real values of the independent variables) and responses of the values of $\mathrm{K}$ and $\mathrm{N}$ for the Langmuir isotherm and $\mathrm{k}$ and $\mathrm{n}$ for the Freundlich isotherm for the

\begin{tabular}{|c|c|c|c|c|c|c|c|c|}
\hline \multicolumn{2}{|c|}{$\begin{array}{c}\text { Independent } \\
\text { variables }\end{array}$} & \multirow{2}{*}{$\begin{array}{c}\text { Removal } \\
(\%)^{*}\end{array}$} & \multicolumn{3}{|c|}{ Langmuir } & \multicolumn{3}{|c|}{ Freundlich } \\
\hline pH & $\begin{array}{c}\text { Temp. } \\
\left({ }^{\circ} \mathrm{C}\right)\end{array}$ & & $\begin{array}{c}\mathrm{K} \\
\left(\mathrm{L} . \mathrm{mg}^{-1}\right)\end{array}$ & $\begin{array}{c}\mathrm{N} \\
\left(\mathrm{mg} \cdot \mathrm{g}^{-1}\right)\end{array}$ & $\mathrm{R}^{2}$ & $\begin{array}{c}\mathrm{k} \\
\left(\mathrm{mg} \cdot \mathrm{g}^{-1}\right)\end{array}$ & $1 / \mathrm{n}$ & $\mathrm{R}^{2}$ \\
\hline $5.5(-1)$ & $20(-1)$ & 40.11 & 0.01 & 85.47 & 0.6980 & 13.80 & 0.269 & 0.9823 \\
\hline $8.5(1)$ & $20(-1)$ & 40.14 & 0.01 & 91.74 & 0.5965 & 9.23 & 0.306 & 0.9813 \\
\hline $5.5(-1)$ & $60(1)$ & 51.21 & 0.03 & 85.47 & 0.9809 & 26.91 & 0.170 & 0.9096 \\
\hline $8.5(1)$ & $60(1)$ & 50.86 & 0.01 & 100.00 & 0.7561 & 15.60 & 0.277 & 0.9651 \\
\hline $7(0)$ & $40(0)$ & 41.87 & 0.01 & 86.21 & 0.809 & 17.57 & 0.234 & 0.9526 \\
\hline $7(0)$ & $40(0)$ & 41.45 & 0.01 & 86.21 & 0.8185 & 17.52 & 0.233 & 0.9583 \\
\hline $7(0)$ & $40(0)$ & 40.76 & 0.01 & 85.47 & 0.8223 & 17.08 & 0.236 & 0.9482 \\
\hline
\end{tabular}

Where: K (equilibrium constant), N (solute mass for adsorbent saturation), k (adsorption capacity) and $\mathrm{n}$ (affinity of the adsorbent-adsorbate system).

* Percentage removal of color evaluated at a concentration of $500 \mathrm{mg} \cdot \mathrm{L}^{-1}$.

The analysis of the linear correlation coefficients $\left(\mathrm{R}^{2}\right)$ showed that the Freundlich model presents higher values; thus the experimental data is more appropriately adjusted, corroborating with that observed in Figure 4.

The positive nitrogen observed in the structure of the bright blue dye (Figure 1) can act as a connection point to conduct the formation of multiple layers, through electrostatic interactions with the anionic groups of the dye itself.

Besinella Junior et al. [28] evaluated the adsorption of the anionic dye yellow gold remazol RNL using activated carbon and observed that the Langmuir model did not fit the data, whereas the Langmuir-Freundlich and Freundlich models were better adjusted better to the adsorption isotherms of this one dye, indicating that its adsorption is heterogeneous and has a multilayer characteristic, a similar phenomenon observed in this study with an anionic as well.

It is observed in Table 3 that the condition that presented the highest adsorptive capacity (k) with the value of $26.91 \mathrm{mg} \cdot \mathrm{g}^{-1}$ had a temperature of $60{ }^{\circ} \mathrm{C}$ and $\mathrm{pH} 5.5$, presenting a reduction of $51.21 \%$ of the color in the aqueous solution of bright blue food coloring at the evaluated concentration (500 mg. $\left.\mathrm{L}^{-1}\right)$.

The analysis of $1 / \mathrm{n}$ values can demonstrate whether the adsorption process is favorable (values between 0 and 1) or unfavorable, and the lower the value of $1 / \mathrm{n}$, the stronger the interaction between the adsorbate and the adsorbent [34,35].

In the case under study, the values of $1 / \mathrm{n}$ were between 0.17 and 0.306 , indicating a favorable adsorptive process in all evaluated conditions. Consistent with the literature, the condition of $\mathrm{pH} 5.5$ and temperature of $60{ }^{\circ} \mathrm{C}$ presented the highest adsorptive capacity (26.91 $\left.\mathrm{mg} \cdot \mathrm{g}^{-1}\right)$, which presented the lowest value for $1 / \mathrm{n}(0.17)$, indicating that this condition is favorable. 
The k data (obtained by the Freundlich isotherm) presented in Table 3 were statistically treated, allowing the obtaining of an empirical coded model for the adsorption of the dye, as presented in Equation 6, which was validated by analysis of variance, with F Falculated (302.93) approximately 32 times greater than $\mathrm{F}_{\text {table }}(9.27)$, with an $\mathrm{R}^{2}$ of 0.998 , allowing the construction of the response surface and the contour curve (Figures 5 and 6)

$$
\text { Adsorption }=16.51-4.05 X_{1}+4.72 X_{2}-1.83 X_{1} X_{2}
$$

Where:

$\mathrm{X} 1 \mathrm{pH}$;

$\mathrm{X} 2$ : temperature.

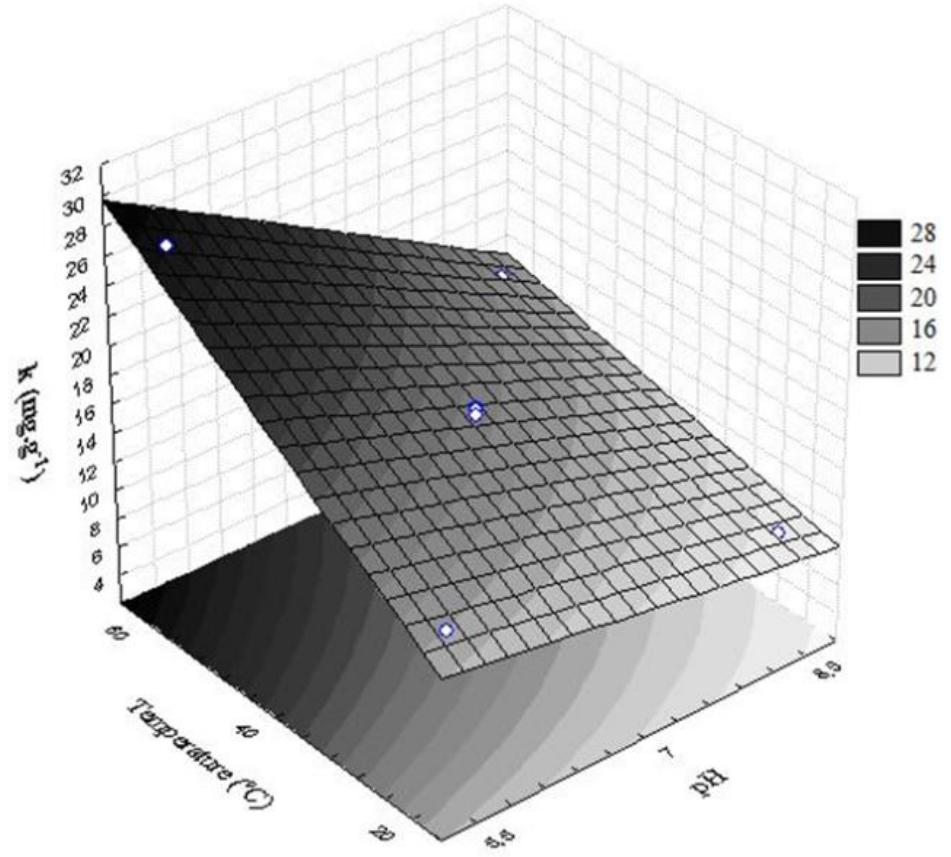

Figure 5. Response surface for the adsorption capacity of the dye diluted in water using powdered activated carbon as an adsorbent.

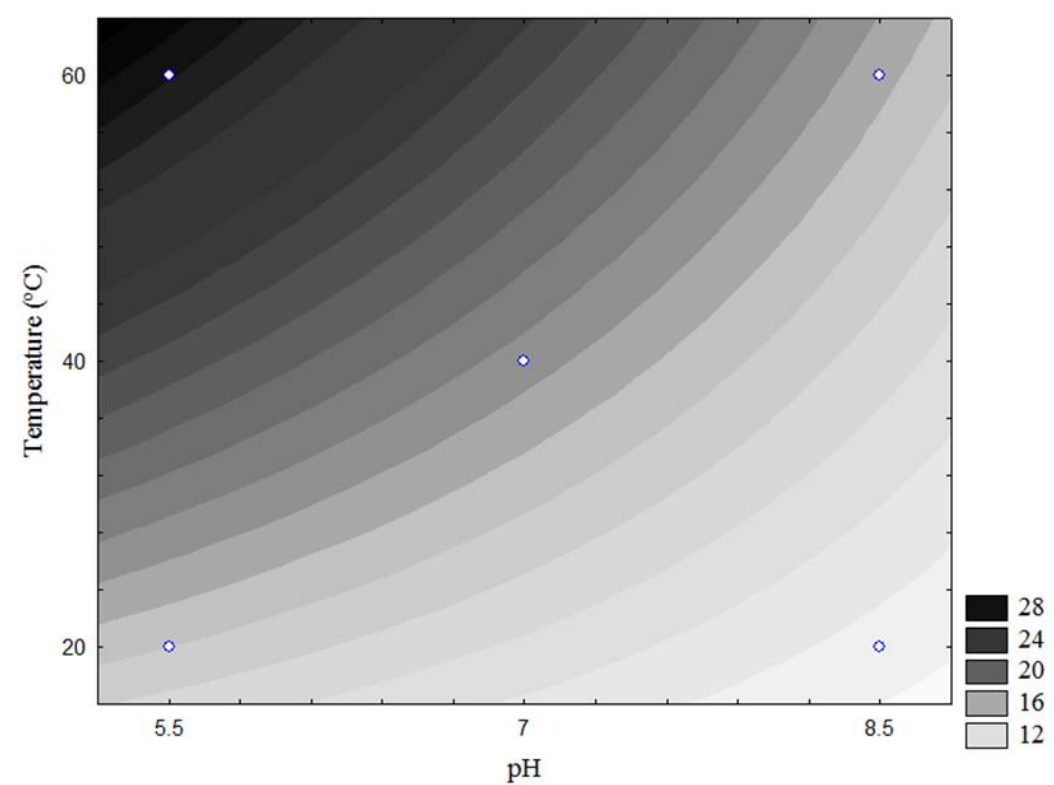

Figure 6. Contour curve for the adsorption capacity of the dye diluted in water using powdered activated carbon as an adsorbent. 
Positive effects are observed for temperature, and negative for $\mathrm{pH}$, that is, the highest adsorptive capacity was observed for temperatures close to $60{ }^{\circ} \mathrm{C}$ and $\mathrm{pH}$ in the range close to 5.5 .

The $\mathrm{pH}$ effect was linked to changes in the surface charge of the adsorbent, which can be determined by its zeta potential and in the structural form of the dye (molecular $\leftrightarrow$ dissociated), which can be determined by its pKa. Considering the PZC of 5.0 presented by the activated carbon evaluated in this study and the pKa of bright blue (5.6 - 6.6) [36], the observed trend is consistent with the literature [34,35], since for all conditions tested, the $\mathrm{pH}$ region evaluated (between 5.5 and 8.5) is above the PZC, indicating that in all the tests, the activated carbon has a negative surface charge, favoring the electrostatic repulsion between the carbon and the bright blue food coloring, a dye with anionic characteristics (Figure 1), whose dissociated (anionic) form, considering its pKa (5.6 - 6.6), tends to intensify with increasing $\mathrm{pH}$, in the evaluated region $(5.5$ - 8.5) and, consequently, in the repulsive effect between dye/adsorbent, leading to a decrease in the adsorptive capacity.

For the temperature, a significant positive effect is observed, indicating that the increase in temperature favors adsorption, that is, that the adsorptive process tends to be endothermic $[34,35]$.

3.2.2.2. Effect of temperature and $\mathrm{pH}$ on the adsorptive capacity of bright blue food coloring diluted in sucrose at $45^{\circ}$ Brix.

In order to make the conditions of the solution as representative as possible to the matrix of the real sample, tests were conducted using a sucrose solution containing $45^{\circ} \mathrm{Brix}$ as a solvent.

To assess the influence of the independent variables, $\mathrm{pH}(5.5,7$ and 8.5) and temperature $\left(20,40\right.$ and $\left.60{ }^{\circ} \mathrm{C}\right)$ in relation to the adsorption capacity of powdered activated carbon for the dye in sucrose solution $45^{\circ}$ Brix , a $2^{2}$ factorial design was carried out, with the adsorption isotherms shown in Figure 7.

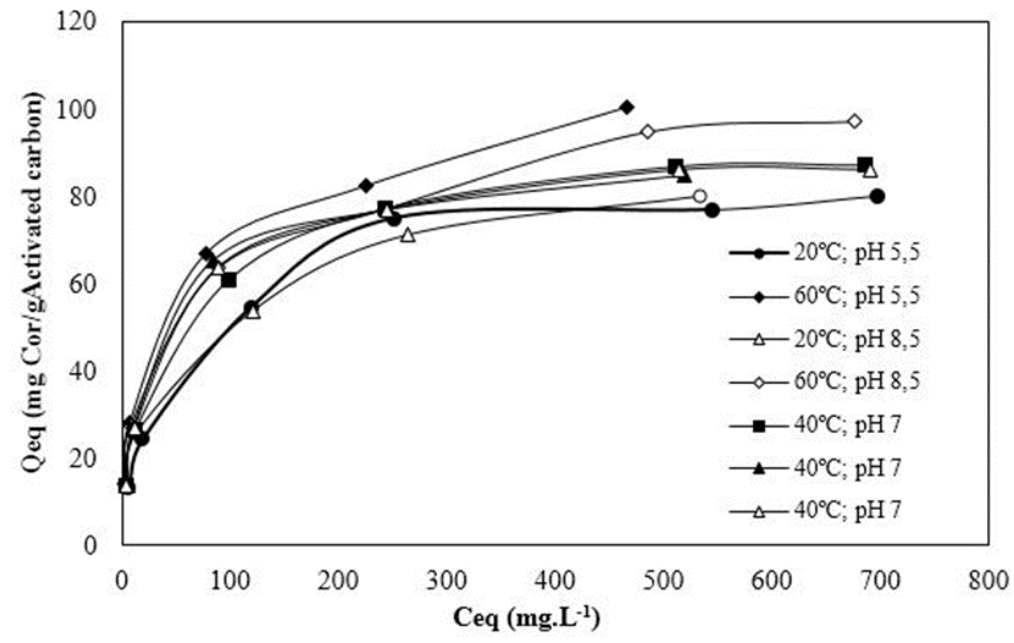

Figure 7. Adsorption isotherms for the dye diluted in $45^{\circ}$ Brix sucrose solution at different temperatures and $\mathrm{pH}$.

The adsorption isotherms obtained for the dye dissolved in sucrose solution presented a different profile from that observed for the adsorption isotherms of the dye dissolved in aqueous solution. For the sucrose solution, the observed profile suggests that it is better adjusted to the Langmuir model, which suggests monolayer adsorption on a surface with a finite number of identical sites [37]. 
Table 4 presents the experimental design with the real and coded values of the independent variables and the values obtained from the Langmuir and Freundlich isotherms for the dye diluted in sucrose solution $45^{\circ}$ Brix.

Table 4. Matrix of the $2^{2}$ experimental design (coded and real values of the independent variables) and responses of the values of $\mathrm{K}$ and $\mathrm{N}$ for the Langmuir isotherm and $\mathrm{k}$ and $\mathrm{n}$ for the Freundlich isotherm for the

\begin{tabular}{|c|c|c|c|c|c|c|c|c|}
\hline \multicolumn{2}{|c|}{$\begin{array}{c}\text { Independent } \\
\text { variables }\end{array}$} & \multirow{2}{*}{$\begin{array}{c}\text { Removal } \\
(\%)^{*}\end{array}$} & \multicolumn{3}{|c|}{ Langmuir } & \multicolumn{3}{|c|}{ Freundlich } \\
\hline pH & $\begin{array}{l}\text { Temp. } \\
\left({ }^{\circ} \mathrm{C}\right)\end{array}$ & & $\begin{array}{c}\mathrm{K} \\
\left(\mathrm{L} . \mathrm{mg}^{-1}\right)\end{array}$ & $\begin{array}{c}\mathrm{N} \\
\left(\mathrm{mg} \cdot \mathrm{g}^{-1}\right)\end{array}$ & $\mathrm{R}^{2}$ & $\begin{array}{c}\mathrm{k} \\
\left(\mathrm{mg} \cdot \mathrm{g}^{-1}\right)\end{array}$ & $1 / \mathrm{n}$ & $\mathrm{R}^{2}$ \\
\hline $5.5(-1)$ & $20(-1)$ & 49.89 & 0.02 & 92.59 & 0.9851 & 7.32 & 0.395 & 0.9756 \\
\hline $8.5(1)$ & $20(-1)$ & 47.34 & 0.02 & 94.34 & 0.9824 & 9.21 & 0.357 & 0.9867 \\
\hline $5.5(-1)$ & $60(1)$ & 54.83 & 0.03 & 103.09 & 0.9901 & 12.51 & 0.353 & 0.9723 \\
\hline $8.5(1)$ & $60(1)$ & 51.34 & 0.03 & 101.01 & 0.9940 & 11.07 & 0.351 & 0.9667 \\
\hline $7(0)$ & $40(0)$ & 51.40 & 0.02 & 97.09 & 0.9949 & 9.89 & 0.361 & 0.9750 \\
\hline $7(0)$ & $40(0)$ & 51.18 & 0.03 & 93.46 & 0.9971 & 10.14 & 0.357 & 0.9352 \\
\hline $7(0)$ & $40(0)$ & 51.22 & 0.03 & 95.24 & 0.9964 & 10.02 & 0.359 & 0.9537 \\
\hline
\end{tabular}

Where: K (equilibrium constant), N (solute mass for adsorbent saturation), k (adsorption capacity), and n (affinity of the adsorbent-adsorbate system).

* Percentage color removal evaluated at a concentration of $500 \mathrm{mg} \cdot \mathrm{L}^{-1}$.

Both models are well suited $\left(\mathrm{R}^{2}>0.93\right)$. However, the Langmuir models have a higher linear correlation $\left(\mathrm{R}^{2}>0.98\right)$, fitting better than Freundlich's to represent the data obtained for the dye diluted in sucrose solution at $45^{\circ} \mathrm{Brix}$, according to the profile observed for isotherms (Figure 7).

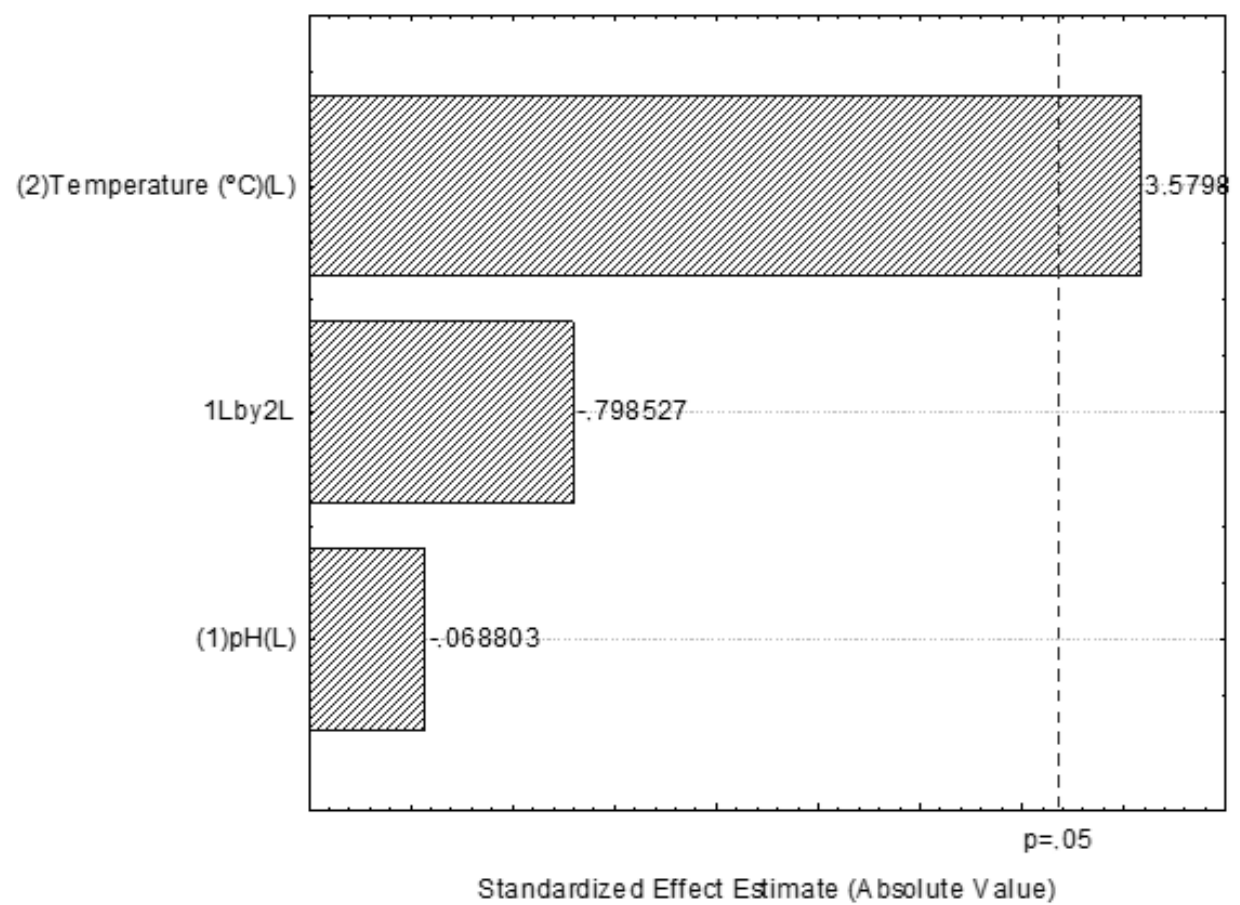

Figure 8. Pareto graph of the adsorption of the dye diluted in a $45^{\circ}$ Brix sucrose solution ( 1 h of contact).

Ozsoy and van Leeuwen [5] investigated the discoloration of solutions of sweet fruit extracts dissolved in deionized water, using activated carbon as an adsorbent, and also concluded that the Langmuir model was the one that best adjusted to the data.

According to the Langmuir model (Table 4), the highest adsorptive capacity ( $\mathrm{N}$ ) in a $45^{\circ}$ Brix sucrose solution, with $103.09 \mathrm{mg} \cdot \mathrm{g}^{-1}$, was obtained for the test conducted with the lowest $\mathrm{pH}(5.5)$ and the highest temperature $\left(60^{\circ} \mathrm{C}\right)$, with a color reduction of $54.83 \%$, for the test conducted with $500 \mathrm{mg} . \mathrm{L}^{-1}$. 
It should be noted that for all experimental conditions evaluated, the adsorptive capacity values for the bright blue dye, obtained by Langmuir $(\mathrm{N})$, in sucrose solution (Table 4), were higher than those obtained in the aqueous solution (Table 3), indicating a positive effect of the presence of sucrose in the adsorptive process. The removal percentage of the bright blue food coloring, at a concentration of $500 \mathrm{mg} . \mathrm{L}^{-1}$, diluted in a solution with sucrose was $3.62 \%$ higher than the removal of the dye diluted in aqueous solution.

In the study of the adsorption of food coloring from sweet fruit solutions by activated carbon carried out by Ozsoy and van Leeuwen [5], the authors found that the food colorants were removed preferentially at the highest concentrations of sugars and organic acids.

The data presented in Table 4 for the Langmuir model were treated statistically, and the effects of the independent variables are presented in the form of a Pareto Graph (Figure 8).

Temperature (Figure 8) had a significant and positive effect $(\mathrm{p}<0.05)$, indicating that higher levels lead to greater adsorption, suggesting that the adsorptive process is endothermic $[34,35]$.

The lack of a significant effect observed for the $\mathrm{pH}$, with a $95 \%$ confidence, may be linked to the presence of sucrose, which, considering its high concentration in the medium (45 ${ }^{\circ}$ Brix), acts by minimizing the anionic character of brilliant blue and activated carbon and, consequently, the repellent dye/adsorbent effect in the studied $\mathrm{pH}$ region, in such a way that there is no effect for this variable. In addition, minimizing the repulsive effect tends to favor adsorption.

This hypothesis corroborates the greater adsorptive capacity obtained by Langmuir $(\mathrm{N})$, observed for the sucrose solution $45^{\circ}$ Brix in relation to the aqueous solution, regardless of the experimental condition evaluated.

\subsection{Tests using the reprocessing solution.}

The reprocessing solution was characterized in terms of $\mathrm{pH}$ and ${ }^{\circ} \mathrm{Brix}$, and the values found were 5.3 and $52^{\circ}$ Brix, respectively. The absorbance spectrum was performed on the reprocessing solution to verify at which wavelengths it absorbs, as shown in Figure 9.

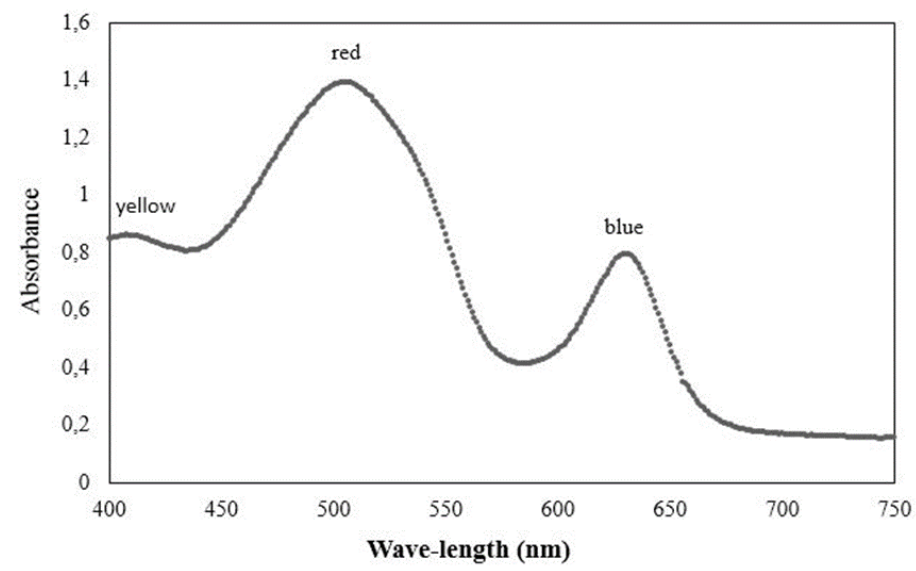

Figure 9. Absorption spectrum of the reprocessing solution (real solution) in the visible region of the spectrum.

Based on the absorption spectra (Figure 9), it is observed that the reprocessing solution showed more intense absorbances at wavelengths 400, 505, and $632 \mathrm{~nm}$, which are characteristic of the complementary colors yellow, red, and blue [38]. The dyes present in the industry's reprocessing syrup have been reported to be tartrazine yellow, red 40, and bright blue. Therefore, the reprocessing syrup is formed by mixing more than one dye, which is 
consistent with the way it is stored, using the same container for reprocessing syrups from different batches, produced with different dyes.

Table 5 shows the objective color $\left(\mathrm{L}^{*}, \mathrm{a}^{*}, \mathrm{~b}^{*}, \mathrm{C}^{*}\right.$, and $\left.\mathrm{H}^{\circ}\right)$ of the crude reprocessing mixture (control) and treated with different concentrations of activated carbon ( 0.334 to 3.334 g. $\left.\mathrm{L}^{-1}\right)$, respectively.

Table 5. Objective color $\left(\mathrm{L}^{*}, \mathrm{a}^{*}, \mathrm{~b}^{*}, \mathrm{C}^{*}\right.$ and $\left.\mathrm{H}^{\circ}\right)$ of the syrup filtered and treated with different concentrations of powdered

\begin{tabular}{|c|c|c|c|c|c|}
\hline $\begin{array}{c}\text { Treatment } \\
\left(\text { gCarbon. } \mathbf{L}^{-1}\right)\end{array}$ & $\mathbf{L}^{*}$ & $\mathbf{a}^{*}$ & $\begin{array}{l}\text { arbon. } \\
\mathbf{b}^{*}\end{array}$ & $\mathbf{C}^{*}$ & $\mathbf{H}^{\mathbf{o}}$ \\
\hline Control & $37.74^{\mathrm{e}} \pm 0.47$ & $10.49^{a} \pm 0.35$ & $9.86^{a} \pm 0.18$ & $14.40^{\mathrm{a}} \pm 0.37$ & $0.73^{\mathrm{ab}} \pm 0.02$ \\
\hline 0.334 & $41.01^{\mathrm{d}} \pm 0.10$ & $9.27^{b} \pm 0.05$ & $9.74^{\mathrm{a}} \pm 0.10$ & $13.45^{\mathrm{b}} \pm 0.07$ & $0.57^{\mathrm{ab}} \pm 0.02$ \\
\hline 0.834 & $43.59^{c} \pm 0.04$ & $6.40^{\mathrm{c}} \pm 0.51$ & $8.37^{\mathrm{b}} \pm 0.14$ & $10.54^{\mathrm{c}} \pm 0.21$ & $0.26^{\mathrm{b}} \pm 0.13$ \\
\hline 1.667 & $46.00^{b} \pm 0.04$ & $1.95^{\mathrm{d}} \pm 0.06$ & $8.05^{\mathrm{c}} \pm 0.03$ & $8.28^{\mathrm{d}} \pm 0.02$ & $0.66^{\mathrm{ab}} \pm 0.18$ \\
\hline 3.334 & $48.98^{a} \pm 0.02$ & $0.01^{\mathrm{e}} \pm 0.00$ & $6.64^{\mathrm{d}} \pm 0.02$ & $6.63^{e} \pm 0.01$ & $1.11^{\mathrm{a}} \pm 0.66$ \\
\hline
\end{tabular}
(Tukey's test).

It is observed that the treatment with powdered activated carbon increases the luminosity $\left(\mathrm{L}^{*}\right)$; that is, the closer to 100 , the clearer the sample is. The statistical treatment showed that all samples showed a significant difference $(\mathrm{p}<0.05)$.

As for the chromaticity parameter $\mathrm{a}^{*}$, which indicates the variation between the colors green (-) and red (+), the values are found in the red region, consistent with the $505 \mathrm{~nm}$ absorbance peak observed in the spectrum (Figure 10), which corresponds to the color red. However, as the amount of carbon increases, the intensity of the red color decreases. Statistically evaluating the data, all samples were statistically different $(\mathrm{p}<0.05)$.

For the chromaticity $b^{*}$, which varies between the blue (-) and yellow (+) colors, the values are found in the yellow region. The filtered syrup and the treatment with $0.334 \mathrm{~g} . \mathrm{L}^{-1}$ of powdered activated carbon did not differ significantly, but they showed a significant difference from the other samples $(\mathrm{p}<0.05)$.

The $C^{*}$ parameter, which represents saturation, is directly related to the concentration of the dye element, representing a quantitative attribute to intensity. Thus, the higher the $\mathrm{C}^{*}$ value, the greater the saturation of colors perceptible to the human eye. Thus, neutral colors have low saturation values, while pure colors have high saturation and are brighter in human perception $[39,40]$.

The sample treated with $3.334 \mathrm{gL}^{-1}$ of activated carbon differed statistically from the sample treated with $0.834 \mathrm{gL}^{-1}(\mathrm{p}<0.05)$, in addition, it is observed that the value of $\mathrm{C}^{*}$ decreases with the increase in the concentration of carbon, this can be seen visually in Figure 10, which shows the visual aspect of the reprocessing syrup after treatment using different proportions of powdered activated carbon, where it is observed that there is a decrease in the color intensity, with an increase in the concentration of carbon.

The $\mathrm{H}^{\mathrm{o}}$, which defines the qualitative attribute of color (reddish, yellowish, greenish tint, etc.) [40], has its value expressed in degrees, corresponding to the three-dimensional color diagram, where $0^{\circ}$ is red, $90^{\circ}$ is yellow, $180^{\circ}$ is green, and $270^{\circ}$ is blue $[39,41]$. The Hue values obtained in this work are close to $0^{\circ}$, indicating red hue; however, the sample treated with 3.334 g. $\mathrm{L}^{-1}$ of activated carbon moved away from the red quadrant, suggesting that part of the red color was adsorbed. In these parameters, treatments differ statistically ( $p<0.05)$. 


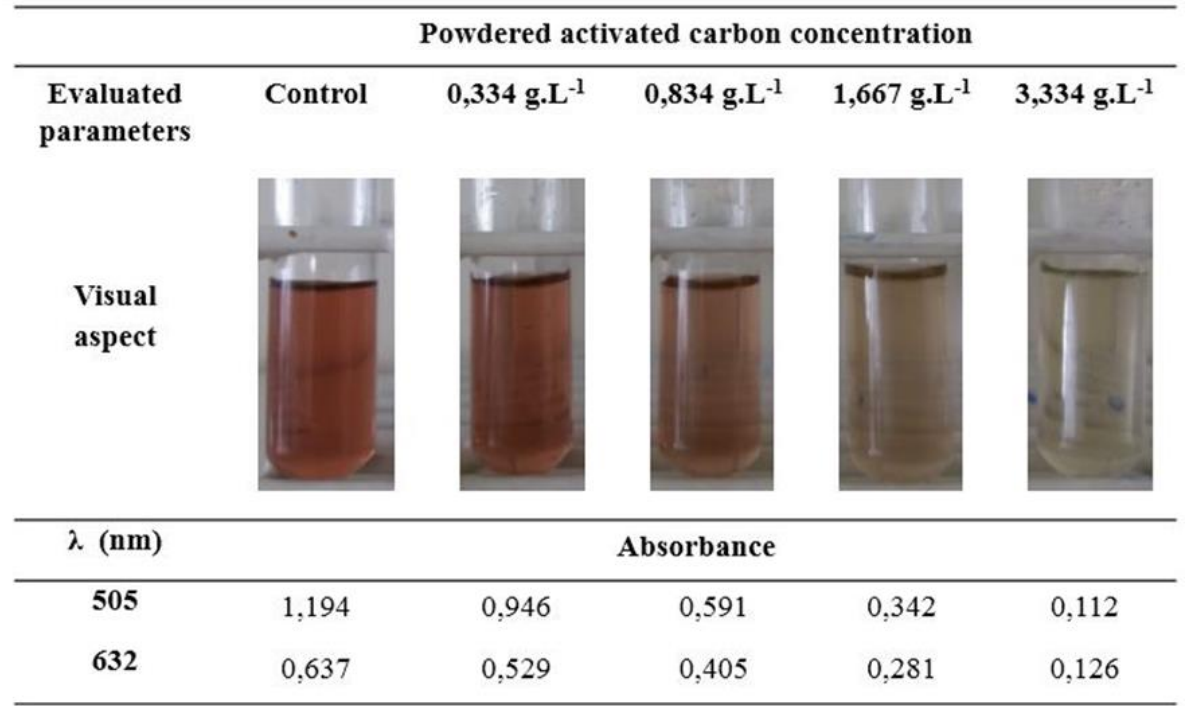

Figure 10. Visual aspect and average absorbance values for the filtered syrup and after treatment with different concentrations of powdered activated carbon.

In visual terms, it is observed that color removal varies proportionally with the amount of carbon, the sample treated with $3.334 \mathrm{~g} . \mathrm{L}^{-1}$ did not show any apparent color, and there was a decrease in the two wavelengths monitored. This decrease is more expressive at the wavelength of $505 \mathrm{~nm}$, which is characteristic of the red color, suggesting that the red dye would have a greater affinity with carbon than the blue dye, whose decrease was not as sharp.

This result corroborates with Ozsoy and van Leeuwen [5], who evaluated the discoloration, using powdered activated carbon, of solutions of sweet fruit extracts containing the food colors FD\&C blue No. 1, FD\&C red No. 40 and FD\&C yellow No. 5, in addition to sugar and organic acids. Their results pointed out that activated carbon was more effective in removing the red color, followed by yellow and finally blue.

According to Gómez, Larrechi, and Callao [42], there may be competition between dyes, with different priorities in the occupation of the adsorption sites of activated carbon by dyes, thus leading to different removal efficiencies between them.

From the absorbance values, the percentage of removal of pigmentation from the reprocessing syrup treated with $3.334 \mathrm{gL}^{-1}$ of powdered activated carbon was calculated, obtaining the values of color reduction of 90.62 and $80.22 \%$, for the wavelength of $505 \mathrm{~nm}$ (red) and $632 \mathrm{~nm}$ (blue), respectively, indicating that, under the studied conditions, this process is efficient to reduce the pigmentation of candy syrups, mainly with a red tint.

Makiya [19] studied the reduction of color in reprocessing syrup at $65^{\circ} \mathrm{Brix}$ and $\mathrm{pH}$ of 3.5 after filtration with powdered activated carbon, accompanying the removal of pigmentation and obtaining the greatest reduction of color on the order of $56 \%$.

3.4. Characteristics of lollipop-type hard candy (strawberry flavor) added with treated reprocessed syrup.

Table 6 and Figure 11 show the results of the objective color $\left(\mathrm{L}^{*}, \mathrm{a}^{*}, \mathrm{~b}^{*}, \mathrm{C}^{*}\right.$, and $\left.\mathrm{H}^{*}\right)$ and the visual characteristics of the hard candy - strawberry flavor, respectively, using different concentrations of reprocessing syrup treated with $3.334 \mathrm{gL}^{-1}$ activated carbon powder.

It is observed that the use of the syrup treated with powdered activated carbon in the composition of the lollipop-type hard candy - strawberry flavor shows a decrease in luminosity $\left(\mathrm{L}^{*}\right)$. 
The chromaticity parameters $\mathrm{a}^{*}$ and $\mathrm{b}^{*}$ indicate that the candy samples are in the red and yellow regions, respectively.

As for parameter $\mathrm{C}^{*}$, the samples with the least amount of reprocessing syrup showed higher saturation, that is, they are brighter in human perception. For the $\mathrm{H}^{\mathbf{0}}$, the values are between $0^{\circ}$ and $90^{\circ}$, indicating the red hue, as expected due to the added red dye.

Table 6. Objective color $\left(\mathrm{L}^{*}, \mathrm{a}^{*}, \mathrm{~b}^{*}, \mathrm{C}^{*}\right.$ and $\left.\mathrm{H}^{*}\right)$ of the finished product with the respective concentrations of reprocessing

\begin{tabular}{c|c|c|c|c|c} 
Syrup & $\mathbf{L}^{*}$ & $\mathbf{a}^{*}$ & $\mathbf{b}^{*}$ & $\mathbf{C}^{*}$ & $\mathbf{H}^{\mathbf{o}}$ \\
\hline $\mathbf{0 \%}$ & $39.57^{\mathrm{a}} \pm 0.865$ & $40.68^{\mathrm{a}} \pm 0.473$ & $20.94^{\mathrm{a}} \pm 0.332$ & $45.76^{\mathrm{a}} \pm 0.572$ & $27.23^{\mathrm{a}} \pm 0.106$ \\
\hline $\mathbf{1 0 \%}$ & $34.79^{\mathrm{b}} \pm 0.622$ & $36.87^{\mathrm{b}} \pm 0.699$ & $15.77^{\mathrm{b}} \pm 0.132$ & $40.10^{\mathrm{b}} \pm 0.693$ & $23.15^{\mathrm{b}} \pm 0.230$ \\
\hline $\mathbf{1 5 \%}$ & $35.07^{\mathrm{b}} \pm 0.852$ & $33.10^{\mathrm{c}} \pm 0.314$ & $13.78^{\mathrm{c}} \pm 0.251$ & $35.85^{\mathrm{c}} \pm 0.380$ & $22.60^{\mathrm{b}} \pm 0.208$ \\
\hline $\mathbf{2 0 \%}$ & $34.16^{\mathrm{b}} \pm 0.482$ & $33.17^{\mathrm{c}} \pm 0.816$ & $14.01^{\mathrm{c}} \pm 0.649$ & $36.02^{\mathrm{c}} \pm 0.561$ & $22.90^{\mathrm{b}} \pm 1.403$ \\
\hline $\mathbf{3 0 \%}$ & $31.97^{\mathrm{c}} \pm 0.792$ & $22.87^{\mathrm{d}} \pm 0.769$ & $7.13^{\mathrm{d}} \pm 0.318$ & $23.95^{\mathrm{d}} \pm 0.821$ & $17.32^{\mathrm{c}} \pm 0.322$ \\
& *Mean followed by same letters/columns indicates that there is no significant difference at the 95\% level (Tukey
\end{tabular}

test).

Figure 11. Visual aspect of the hard candy with different concentrations of the reprocessing syrup.

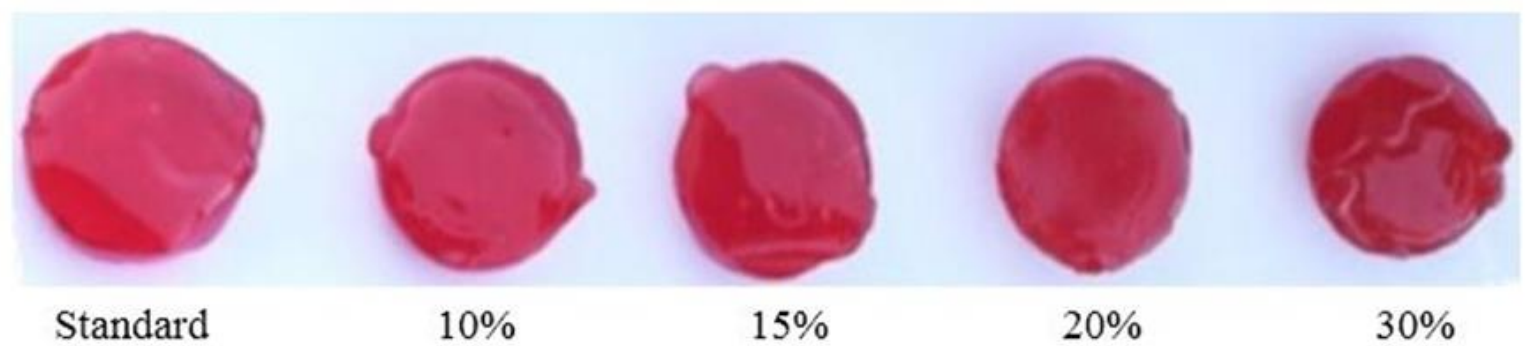

For all evaluated parameters, the statistical treatment showed that the candies containing the treated syrup differ $(\mathrm{p}<0.05)$ from the standard and that when adding treated reprocessing syrup in the 10 to $20 \%$ range, there is no significant difference

The lollipop-type hard candy samples were submitted to sensory analysis, and the average score of the tasters for the visual color is shown in Table 7.

Table 7. Average score of the tasters for the visual color of the samples with different concentrations of reprocess.

\begin{tabular}{c|c} 
Reprocess & Average score of tasters \\
\hline $\mathbf{0 \%}$ (Standard) & $4.96^{\mathrm{a}}$ \\
\hline $\mathbf{1 0 \%}$ & $5.50^{\mathrm{a}}$ \\
\hline $\mathbf{1 5 \%}$ & $6.00^{\mathrm{a}}$ \\
\hline $\mathbf{2 0 \%}$ & $7.04^{\mathrm{b}}$ \\
\hline $\mathbf{3 0 \%}$ & $7.82^{\mathrm{b}}$
\end{tabular}

* Means followed by the same letters indicate that there is no significant difference in relation to the standard sample with 95\% confidence (Dunnett test). Score scale: 9 Extremely more intense than S, 8 Much more intense than S; 7 Moderately more intense than S; 6 Slightly more intense than S; 5 Same as standard; 4 Slightly less intense than S; 3 Moderately less intense than S; 2 Much less intense than S; 1 Extremely less intense than S.

Visual sensory analysis of strawberry-flavored hard candy samples made with different concentrations of reprocessing syrup, after analysis of variance - ANOVA for the Control Difference test showed that when using concentrations greater than or equal to $20 \%$, there is a significant difference $(\mathrm{p}<0.05)$ in relation to the standard sample ( $0 \%$ reprocess), visibly altering the color identified by the tasters. Thus, indicating that it is possible to add up to $15 \%$ of reprocessing syrup in the formulation of hard candy - strawberry flavor.

In the study developed by Makiya [5], after reducing $56 \%$ of the color in the reprocessing syrup, up to $50 \%$ of the syrup treated in the hard candy formulation was added, which did not change the colorimetric characteristics of the product, but reduced the shelf life of the product by half. 


\section{Conclusions}

In relation to the adsorptive tests, the granulometry of the carbon influenced the adsorptive capacity of the bright blue food coloring, and the powdered carbon showed greater efficiency (61\% and $61.6 \%$, for the aqueous solution and with sucrose, respectively).

The Freundlich isotherm was the model that best fitted the experimental data for the adsorptive capacity of the bright blue food coloring diluted in distilled water, suggesting a multilayer coverage and heterogeneous distribution. However, for the dye diluted in sucrose solution $45{ }^{\circ}$ Brix, the most appropriate model was Langmuir's, indicating monolayer adsorption and homogeneous distribution.

The evaluation of the influence of $\mathrm{pH}$ and temperature through the experiment planning showed that for dye diluted in distilled water, the interaction between variables and $\mathrm{pH}$ showed a significant and negative effect, whereas for temperature, the effect was significant and positive $(\mathrm{p}<0.05)$. However, for the dye diluted in sucrose solution $45^{\circ}$ Brix, only the temperature parameter had a significant and positive effect $(\mathrm{p}<0.05)$.

Regarding the removal of pigmentation from the bright blue food coloring, the temperature condition of $60{ }^{\circ} \mathrm{C}$ and $\mathrm{pH} 5.5$ provided the best adsorptive capacity (k) and color reduction, with values of $26.91 \mathrm{mg} \cdot \mathrm{g}^{-1}$ and $51.21 \%$, respectively. As for the dye diluted in sucrose solution, also under the same condition, the highest adsorptive capacity $(\mathrm{N})$ was 103.09 $\mathrm{mg} \cdot \mathrm{g}^{-1,}$ and the color reduction was $54.83 \%$.

The treatment of the reprocessing syrup with 3.334 g.L. ${ }^{-1}$ of powdered activated carbon was efficient in removing the pigmentation, mainly the red color $(505 \mathrm{~nm})$, which showed a $90.62 \%$ reduction in intensity.

The statistical treatment of the data obtained from the visual sensory analysis of the lollipop-type hard candy did not indicate any difference between the control ( $0 \%$ treated syrup) and the product made with up to $15 \%$ reprocessing syrup.

Thus, the use of powdered activated carbon presents an alternative for removing pigments in candy syrup, facilitating its application in the preparation of other products within the industry, generating less waste, and greater savings in waste management.

\section{Funding}

This research received no external funding.

\section{Acknowledgments}

The authors thank National Council for Scientific and Technological Development (CNPq), Coordination for the Improvement of Higher Education Personnel (CAPES), and Research Support Foundation of the State of Rio Grande do Sul (FAPERGS).

\section{Conflicts of Interest}

The authors declare no conflict of interest.

\section{References}

1. Ozgun, H.; Karagul, N.; Dereli, R.K.; Ersahin, M.E.; Coskuner, T.; Ciftci, D.I.; Ozturk, I.; Altinbas, M. Confectionery industry: a case study on treatability-based effluent characterization and treatment system performance. Water Sci. Technol. 2012, 66, 15-20, https://doi.org/10.2166/wst.2012.094. 
2. Zajda, M.; Aleksander-Kwaterczak, U. Wastewater Treatment Methods for Effluents from the Confectionery Industry - an Overview. J. Ecol. Eng. 2019, 20, 293-304, https://doi.org/10.12911/22998993/112557.

3. Moretto, D. Assessment of removal of color from residual syrup from candy industry using hydrogen peroxide promoted with hydroxyl ion. Dissertation. Master in Food Engineering - Universidade Regional Integrada do Alto Uruguai e das Missões, Erechim, 2011.

4. Daoud, M.; Benturki, O.; Girods, P.; Donnot, A. Fontana, S. Adsorption ability of activated carbons from Phoenix dactylifera rachis and Ziziphus jujube stones for the removal of commercial dye and the treatment of dyestuff wastewater. Microchem. J. 2019, 148, 493-502, https://doi.org/10.1016/j.microc.2019.05.022.

5. Ozsoy, H.D.; van Leeuwen. (HANS), J. Removal of color from fruit candy waste by activated carbon adsorption, J. Food Eng. 2010, 101, 106-112, https://doi.org/10.1016/j.jfoodeng.2010.06.018.

6. Bernal, M.; Ruiz, M.O.; Geanta,R.M.; Benito, J.M.; Escudero, I. Colour removal from beet molasses by ultrafiltration with activated charcoal. Chem. Eng. 2016, 283, 313-322, https://doi.org/10.1016/j.cej.2015.07.047.

7. Ganesan, S.; Amirthalingam, M.; Arivalagan, P.;Govindan, S.; Palanisamy, S.; Lingassamy, A.P.; Ponnusamy, V.K. Absolute removal of ciprofloxacin and its degraded by-products in aqueous solutions using an efficient eletrochemical oxidation process coupled with adsorption treatment technique. J. Environ. Manage. 2019, 245, 409-417, https://doi.org/10.1016/j.jenvman.2019.05.092.

8. Li, X.; Han, D.; Zhang, M.; Li, B.; Wang, Z.; Gong, Z., Liu, P.; Zhang, Y.; Yang, X. Removal of toxic dyes from aqueous solution using new activated carbon materials developed from oil sludge waste. Colloids Surf. A 2019, 578, https://doi.org/10.1016/j.colsurfa.2019.05.066.

9. Streit, A.F.M.; Côrtes, L.N.; Druzian, S.P.; Godinho, M.; Collazzo, G.C.; Perondi, D.; Dotto, G.L. Development of high quality activated carbon from biological sludge and its application for dyes removal from aqueous solutions. Sci. Total Environ. 2019, 660, 277-287, https://doi.org/10.1016/j.scitotenv.2019.01.027.

10. Zhang, Y.; Pan, K.; Zhong, Q. Characteristics of activated carbon and carbon nanotubes as adsorbents to remove annatto (norbixin) in cheese whey. J. Agric. Food Chem. 2013, 61, 9230-9240, https://doi.org/10.1021/jf402537y.

11. Zhang, Y.; Campbell, R.; Drake, H.; Zhong, Q. Decolorization of Cheddar cheese whey by activated carbon. J. Dairy Sci. 2015, 98, 2982-2991, https://doi.org/10.3168/jds.2014-9159.

12. Miyagi, A.; Nabetani, H.; Nakajima, M. Decolorization of Japanese soy sauce (shoyu) using adsorption. $J$. Food Eng. 2013, 116, 749-757, https://doi.org/10.1016/j.jfoodeng.2012.12.041.

13. Panchangam, S.C.; Janakiraman, K. Sorptive removal of color from aqueous coffee and tea infusions. Desalin. Water Treat. 2012, 50, 338-347, https://doi.org/10.1080/19443994.2012.720107.

14. López, F.; Medina, F.; Prodanov, M.; Güell, C. Oxidation of activated carbon: application to vinegar decolorization. J. Colloid Interface Sci. 2003, 257, 173-178, https://doi.org/10.1016/S0021-9797(02)000401 .

15. Guliyev, N.G.; Ibrahimov, H.J.; Alekperov, J.A.; Amirov1, F.A.; Ibrahimova, Z.M. Investigation of activated carbon obtained from the liquid products of pyrolysis in sunfower oil bleaching process. Int. J. Ind. Chem. 2018, 9, 277-284, https://doi.org/10.1007/s40090-018-0156-1.

16. Chetima, A.; Wahabou, A.; Zomegni, G. Rahman, A.N.; Nde, D.B. Bleaching of neutral cotton seed oil using organic activated carbon in a batch system: kinetics and adsorption isotherms. Processes 2018, 6, 22-35, https://doi.org/10.3390/pr6030022.

17. Amaral, T.N.; Junqueira, L.A.; Alves, C.C.O.; Oliveira, N.L.; Prado, M.E.T.; Resende, J.V.de. Extraction of hydrocolloids from Pereskia Aculeata Miller: reuse of process residue as activated carbon for the pigmentremoval phase. Food Sci. Technol. 2018, 38, 77-85, https://doi.org/10.1590/1678-457x.10517.

18. Solís-Fuentes, J.A.; Hernández-Ceja, Y.; Hernández-Medel, M.R.; García-Gómez' R.S.; Bernal-González, M.; Mendoza-Pérez, S.; Durán-Domínguez-de-Bazúa, M.C. Quality improvement of jaggery, a traditional sweetener, using bagasse activated carbon. Food Biosci. 2019, 32, https://doi.org/10.1016/j.fbio.2019.100444.

19. Makiya, I.K. Color removal of grouts from hard candy discharges, aiming at industrial reuse. Dissertation. Master in Food Engineering - Universidade Estadual de Campinas, Campinas, 1996.

20. Brazilian Association of Technical Standards - ABNT. Powdered activated carbon: Determination of iodine number. MB-3410. Rio de Janeiro, 1991.

21. Zhu, W.; Koziel, J.A.; Cai, G.; Brehm-Stecher, B.F.; Özsoy, H.D.; van Leeuwen, J.H. Ozonation-based decolorization of food dyes for recovery of fruit leather astes, J. Agr. Food Chem. 2013, 61, 8198-8206, https://doi.org/10.1021/jf402590t.

22. Stewart, M.R.; Zipser, M.W.; Watts, B.M. The use of reflectance spectrophotometry for the assay of raw meat pigments. J. Food Sci. 1965, 30, 464-469, https://doi.org/10.1111/j.1365-2621.1965.tb01787.x.

23. Grassi, M.; Kaykioglu, G.; Belgiorno, V.; Lofrano, G. Removal of Emerging contaminants from water and wastewater by adsortion process, In: Emerging Compounds Removal from Wastewater: Natural and Solar Based Treatments. Lofrano, G. (Ed), Spreinger, Dordrecht, 2012; pp. 15-37, https://doi.org/10.1007/978-94007-3916-1. 
24. Queiroz, M.I.; Treptow, R.O. Sensory analysis for the evaluation of food quality. Editora da FURG: Rio Grande. Brazil. 2006; pp. 268.

25. Rao, M.M.; Reddy, D.H.K.K.; Venkateswarlu, P.; Seshaiah, K. Removal of mercury from aqueous solutions using activated carbon prepared from agricultural by-product/waste. J. Environ. Manage. 2009, 90, 634-643, https://doi.org/10.1016/j.jenvman.2007.12.019.

26. Müller, C.C.; Raya-Rodriguez, M.T.; Cybis, L.F. Adsorção em carvão ativado em pó para remoção de microcistina de água de abastecimento público. Eng. Sanit. Ambient. 2009, 14, 29-38, https://doi.org/10.1590/S1413-41522009000100004.

27. Machrouhi, A.; Alilou, H.; Farnane, M.; El Hamidi, S.; Sádiq, M.; Abdennouri, M.; Tounsadi, H.; Barka, N. Statistical optimization of activated carbon from Thapsia transtagana stems and dyes removal efficiency using central composite design. Journal of Science: Advanced Materials and Devices 2019, 4, 544-553, https://doi.org/10.1016/j.jsamd.2019.09.002.

28. Besinella Junior, E.; Matsuo, M.S.; Walz, M.; Silva, A.F.da; Silva, C. Efeito da temperatura e do tamanho de partículas na adsorção do corante Remazol Amarelo Ouro RNL em carvão ativado. Acta Sci-Technol. 2009, 31, 185-193, https://doi.org/10.4025/actascitechnol.v31i2.1310.

29. Yagub, M.T.; Sen, T.K.; Afroze, S.; Ang, H.M. Dye and its removal from aqueous solution by adsorption: a review. Adv. Colloid Interface Sci. 2014, 209, 172-184, https://doi.org/10.1016/j.cis.2014.04.002.

30. Djilani, C.; Zaghdoudi, R.; Djazi, F.; Bouchekima, B.; Lallam, A.; Modarressi, A.; Rogalski, M. Adsorption of dyes on activated carbon prepared from apricot stones and commercial activated carbon. J. Taiwan Inst. Chem. E. 2015, 53, 112-121, https://doi.org/10.1016/j.jtice.2015.02.025.

31. Aljeboree, A.M.; Alshirif, A.N.; Alkaim, A.F. Kinetics and equilibrium study for the adsorption of textile dyes on coconut shell activated carbon. Arab. J. Chem. 2017, 10, 3381-3393, https://doi.org/10.1016/j.arabjc.2014.01.020.

32. Allen, S.; Koumanova, B. Decolourisation of water/wastewater using adsorption. J. Chem. Technol Metall. 2005, 40, 175-192.

33. Freundlich, H.; Heller, W. The Adsorption of cis- and trans-Azobenzene. J. Am. Chem. Soc. 1939, 61, 22282230, https://doi.org/10.1021/ja01877a071.

34. Nascimento, R.F.; de Lima, A.C.A.; Vidal, C.B.; de Q. Melo, D.; Raulino, G.S.C. Adsorption: theoretical aspects and environmental applications. Imprensa Universitária: Fortaleza. Brazil. 2014; pp.256.

35. Delle Site, A. Factors affecting sorption of organic compounds in natural sorbent/water systems and sorption coefficients for selected pollutants. a review. J. Phys. Chem. Ref. Data 2001, 30, 187-437, https://doi.org/10.1063/1.1347984.

36. Zhang, L.; Sellaoui, L.; Franco, D.; Dotto, G.L.; Bajahzar, A.; Belmabrouk, H.; Bonilla-Petriciolet, A.; Oliveira, M.L.S. Li, Z. Adsorption of dyes brilliant blue, sunset yellow and tartrazine from aqueous solution on chitosan: Analytical interpretation via multilayer statistical physics model. Chem. Eng. 2020, 382, https://doi.org/10.1016/j.cej.2019.122952.

37. Langmuir, I. The adsorption of gases on plane surfaces of glass, mica and platinum. J. Am. Chem. Soc. 1918, 40, 1361-1403, https://doi.org/10.1021/ja02242a004.

38. Almeida, V.V.; Canesin, E.A.; Suzuki, R.M.; Palioto, G.F. Análise qualitativa de proteínas em alimentos por meio de reação de complexação do íon cúprico. Qui. Nova Escola 2013, 35, 34-40.

39. Shewfelt, R.L.; Thai, C.M.; Davis, J.W. Prediction of changes in color of tomatoes during ripening at different constant temperatures. J. Food Sci. 1988, 53, 1433-1437, https://doi.org/10.1111/j.13652621.1988.tb09293.x.

40. Pathare, P.B.; Opara, U.L.; Al-Said, F.A. Colour measurement and analysis in fresh and processed foods: a review. Food Bioprocess Technol. 2013, 6, 36-60, https://doi.org/10.1007/s11947-012-0867-9.

41. McGuire, R.G. Reporting of objective color measurements. HortScience 1992, 27, 1254-1255, https://doi.org/10.21273/HORTSCI.27.12.1254.

42. Gómez, V.; Larrechi, M.S.; Callao, M.P. Kinetic and adsorption study of acid dye removal using activated carbon. Chemosphere 2007, 69, 1151-1158, https://doi.org/10.1016/j.chemosphere.2007.03.076. 